\title{
João Eduardo Rodrigues Villalobos
}

Beatriz A. Moura Fétizon

Faculdade de Educação - Universidade de São Paulo

João Villalobos não foi meu professor na graduação. Nem foi meu colega no curso de Filosofia. Foi meu calouro, nos idos de 1949. Eu cursava o segundo ano, na Maria Antonia, quando ele chegou. Não tivemos contato acadêmico muito próximo como alunos. As únicas disciplinas que cursamos juntos foram: as de Martial Guerroult (então Decano do Colégio de França), que vinha nos dar cursos intensivos nos segundos semestres, ao longo de três (mais?) anos consecutivos; Historiografia da História da Filosofia, Descartes, e Kant - pelos menos foram esses os que cursei; cursos integrantes da cadeira de História da Filosofia, do professor Lívio Teixeira. Em 51, formei-me e nunca mais voltei. Andei vagando por aí, nas mais estranhas atividades que incorporaram desde aulas de filosofia para o clássico e o científico, até teatro, televisão, trabalho em firmas belgas e francesas e outros que tais. Finalmente, em 1972, por razões totalmente estranhas à vida acadêmica, fui bater à porta da Faculdade de Filosofia (que eu supunha ser, ainda, "Ciências e Letras" - eu nem sabia da Reforma Universitária...) atrás de um curso de mestrado. Surpresa! 0 meu povo não estava mais lá. "Meu povo”, na época, só poderiam ser meus contemporâneos, pois meus professores estariam todos já aposentados (não estavam: Eurípedes Simões de Paula, meu antigo Diretor ainda estava por lá, na chefia da História, e me recebeu muito bem). Bem, consegui a pista de alguns contemporâneos (do curso de Filosofia). Heládio César Gonçalves Antunha e Roque Spencer Maciel de Barros (meus veteranos), Ruy Afonso Costa Nunes e João Eduardo Rodrigues Villalobos (meus calouros) estavam na Faculdade de
Educação. Eu não sabia que existia. Havia um outro veterano e velho amigo, mas também fora da Filosofia - ô meu Deus, que falta fazem os acentos diferenciais: estou falando de fora e não de fora... - o Dante Moreira Leite, que estava na Psicologia. Fui à Faculdade de Educação. Inscrevi-me no mestrado. Encontrei os amigos perdidos. Indiquei João Villalobos para meu orientador. Na entrevista, perguntou-me: “Por que me escolheu?". Respondi: "Por três razões. Te conheço de há muito; te admiro pela capacidade intelectual e pelo acervo de conhecimentos; e confio em você como pessoa e como orientador. Sei, portanto, que, de um lado, estarei muito bem orientada e, de outro, sua retidão impedirá que nosso velho conhecimento o constranja se tiver que me recusar por falta de condições ou me eliminar por falta de aproveitamento". João pensou um pouco e me disse: "Mas vou ter que recusá-la. Por outras razões: nosso parentesco é um entrave a que possa orientá-la oficialmente. Estarei sempre a sua disposição para discutir questões, esclarecer dúvidas (e como cumpriu a promessa à risca!), mas terei que encaminhá-la a outro orientador. Já falei com o Heládio. Ele a aceita". Quando, anos mais tarde, já ao final de meu doutoramento, o Heládio - que continuava meu orientador - teve que se aposentar e abandonar a orientação, por razões de saúde, esse mesmo argumento voltaria à tona. Pedi a Maria de Penha Villalobos que me aceitasse, substituindo o Heládio. Ela se lembrava bem do argumento do parentesco e foi consultar o marido. João levou uma eternidade para decidir-se e, já ao final de meu prazo, Maria da 
Penha conseguiu dobrá-lo com um contra-argumento irretorquível: "Mas que parentesco, João! Vocês são primos sei lá em que grau e, para mais, eu não sou prima dela”. E pronto. Ganhei uma grande orientadora.

Enfim, foi assim, no mestrado, que começou minha convivência acadêmica com João Villalobos na Faculdade de Educação. João fizera um longo caminho nos anos em que estivéramos separados, e me dava, agora, uma poeira de séculos de estrada. Era um pensador, um estudioso, um filósofo e um Mestre. Foi sobre o Mestre que falei no artigo que escrevi, a pedido de Gilda Maciel de Barros, para o número especial que o Departamento de Filosofia preparava sobre o professor Villalobos. Não vou repeti-lo aqui. Mas, entre o mestrado e o doutoramento, fiz quatro cursos com ele. Quer se tratasse de um curso centrado sobre a lógica, a epistemologia, a filosofia da ciência, ou a metafísica, foram sempre cursos magnos de $\mathrm{Hu}$ manidade. Quando, pela Comissão Editorial desta Revista, a professora Belmira Oliveira Bueno pediu-me três ou quatro páginas sobre o professor Villalobos, pensei em passar em revista esses cursos. Fui rever o material. Era impossível. Rever tais cursos daria um livro. Fiquei tentada a começar um trabalho de transcrição de todas as minhas anotações em vista de uma publicação. Não faria justiça ao que foram aquelas aulas. Em cada um dos cursos, mergulhávamos numa busca sem fim pelos meandros de vinte e seis séculos do pensamento ocidental e, não bastasse, íamos sondando o que viera antes disso e nos debatendo na bruma espessa do que ainda está por vir. Filósofos, cientistas, literatos em prosa e em verso, teatrólogos, cineastas, pintores e escultores saíam de seus es- caninhos, de seus museus, de suas bibliotecas e de suas tumbas para provocar-nos e aturdir-nos sob pretexto de acrescentar luzes a nossas buscas. Saíamos de cada aula iluminados e confusos. Grandes e minúsculos. Saciados e insatisfeitos. É possível que não nos tornássemos melhores, mas nunca mais seriamos os mesmos. Uma pequena amostra, para tentar mostrar de que é que estou falando, pode ser o temário, que transcrevo a seguir, de um dos cursos que fiz, no mestrado, com o professor Villalobos. Título do curso: Culpa e Liberdade. Temas a seres desenvolvidos:

1. A revelação da culpa: "quem sou eu?"

2. A revelação de Silene: a origem da tragédia.

3. A separação misteriosa e o gosto do pecado: a marca de Caim.

4. A explicação do crime e a satisfação do culpado.

5. A absolvição psicanalítica: o auto-batismo freudiano.

6. Crime e castigo: a inocência na casa dos mortos.

7. O sentimento original da culpa e a idéia de liberdade.

8. A inocência de Deus: a questão da teodicéia.

9. 0 ódio à baleia branca.

10. 0 "único" e sua culpa.

11. Os inocentes agrupados e a culpa do "outro". A delinqüência coletiva.

12. Educação e culpa: o pessoal e o coletivo. Uma filosofia da esperança. Uma filosofía da esperança. João Eduardo Villalobos. Encravada nos labirintos de toda humana angústia. 